\title{
Twenty Years of Cerebellar Degeneration Research at the Department of Pathological Physiology, Faculty of Medicine, Pilsen, Charles University
}

\author{
F. VOŽEH ${ }^{1,2}$
}

${ }^{1}$ Department of Pathophysiology, Faculty of Medicine in Pilsen, Charles University, Pilsen, Czech Republic, ${ }^{2}$ Laboratory of Neurodegenerative Disorders, Biomedical Centre, Faculty of Medicine in Pilsen, Charles University, Pilsen, Czech Republic

Received April 9, 2018

Accepted September 17, 2018

\begin{abstract}
Summary
Mutant Lurcher mice represent an animal model of naturally occurring cerebellar degeneration. A gene mutation causes the demise of all Purkinje cells, as along with certain other types, as well as the functional elimination of the cerebellar cortex. Involvement in the research using this model of the $\mathrm{C} 3 \mathrm{H}$ strain began at the Department of Physiology, UCL in 1995/96. It continued in scientific cooperation with other European laboratories where we obtained Lurcher mice of the B6CBA strain. The aim of the effort was first to identify the extent to which the cerebellum is involved in the higher nervous activity, i.e. cognitive and other functions. In that research, use was made of an entire array of methodological procedures to examine learning, memory, motor functions and emotional behavior. It was completed with an electrophysiological examination of the brain and special microscopic procedures. The results demonstrated that the cerebellum (aside from its traditional tasks) does in fact play a significant role in cognitive function, emotions, etc. It was further found that the neurodegenerative processes also affected the immune and endocrine functions, confirming the concept of the unity of the psychoneuroendocrine-immune system. Surprisingly, despite their neurological impairment, the affected animals were able to learn to some extent and, make progress with physical training, improving not only their motor skills but also learning and memory, including deferring of signs of aging. These particular findings may prove useful for human medicine.
\end{abstract}

\section{Key words}

Lurcher mice • Cerebellar degeneration • Spinocerebellar ataxias

- Neurotransplantation

\section{Corresponding author}

F. Vožeh, Department of Pathophysiology, Faculty of Medicine in Pilsen, Charles University, Alej Svobody 1655/76, 32300 Plzeň, Czech Republic. E-mail: frantisek.vozeh@lfp.cuni.cz

\section{Introduction}

The year 2017 marked 20 years since the Institute of Pathological Physiology of the Faculty of Medicine, Charles University in Pilsen, Czech Republic, launched consistent research of cerebellar degeneration on animal models. The Lurcher $(+/ \mathrm{Lc})$ mutant mice with which the research began are one of the animal models of naturally occurring cerebellar degeneration. In essence, these are heterozygous individuals, in which the cause of the impairment is a disappearance of practically all Purkinje cells and a major portion of granular cells in the cerebellum cortex, as well as a significant portion of the neurons in the inferior olive due to a genetic mutation (Phillips 1960, Caddy and Biscoe 1979). This causes an entire functional elimination of the cerebellar cortex and thus also of the regulation of all neural processes that the cerebellum normally significantly affects. Upon crossing a heterozygous individual with a healthy one, approximately half of the offspring in the nest are again $+/$ Lc and the other half are healthy individuals of the wild 
type $(+/+)$, presenting an ideal control group.

The involvement of the research facility in using this model initiated at the Department of Physiology, University College London (UCL) in 1995-1996. Lurcher mice were obtained here of the $\mathrm{C} 3 \mathrm{H}$ type. Then subsequent further scientific collaboration with a number of European laboratories continued through involvement with the EU COST Program in the area of neurosciences. Lurcher mice of the B6CBA strain were also obtained from the University of Brussels within this collaboration. The goal of the research was to identify the degree to which the cerebellum is involved in the higher nervous activity (cognitive and subsequently other functions) as well as to further explore the pathogenetic mechanisms of genetically conditioned cerebellar degenerations, including possibilities to affect them. The primary drivers for this experimental research were findings indicating that the cerebellum contains more neurons than the cerebral cortex (Glickstein 1992) as well as the excellent animal models of Lurcher mice available at UCL. Further publications released at the time confirmed that this direction for the research was correct. These studies gradually proved that the cerebellar pathways represent two-way connections to practically all main structures of the brain (Schmahmann 1996, Schmahmann and Pandya 1997, Middleton and Strick 2001). Further, they also began to prove that, aside from the traditional role in the area of motor skills and balance, the cerebellum also participates in cognitive functions, the formation of language, learning, memory, emotions and another processes (Schmahmann and Sherman 1997, Buckner 2013, Dennis and Schutter 2013, Malinová-Ševčíková et al. 2014, Tüdös et al. 2018). Thus, it became apparent that in case of the cerebellum, much as in other parts of the body, nothing is purposeless. It is also clear that the enormous volume of neurons that, in the case of humans, is now known to represent $80 \%$ of all nervous cells in the brain (Herculano-Houzel 2010) and the numerous connections of the cerebellum with other nervous structures are not autotelic but form a high-performance functional potential.

\section{Experimental procedures}

At first, the experimental subjects of the ontogenetically focused research of cerebellar degenerations in animal models were the abovementioned +/Lc, derived from two strains $(\mathrm{CH} 3$, B6CBA). Later, PCD (Purkinje cell degeneration) mice from similarly naturally formed mutants were included. Of the precise models of human spinocerebellar ataxias (SCA) artificially formed through genetic engineering methods, further experiments were performed with transgenic mice of the SCA1 and SCA 2 type.

In these experiments an entire array of both traditional and continually updated methodology processes were used for examining learning, memory, motor skills and emotional behavior. Electrophysiological examinations of the brain also contributed to important findings, along with variously conceived microscopic examinations. From the beginning, animals were tested in learning and memory (practically from the earliest age to maturity), using two methods of passive avoidance. The 'step through' version was used for animals from birth (P0) to (P10), and the 'step down' method for older and adult animals.

The standard Morris water maze method was used for testing spatial learning and memory. Various experiment protocols were used because, unlike in the case of previous avoidance methods, a motor skill impairment that gradually develops in impaired individuals does not play a role while swimming. A classic rotarod method (a test mouse sustaining being turned around a rod) served to examine motor function. The CatWalk (capable of evaluating up to 14 parameters at once) and DigiGait (forced motion on a treadmill belt) systems were used for the more detailed evaluation of walking skills.

In studying emotional behaviors, the 'elevated plus maze' method was used to establish anxiety levels. A special device system was used for the examination of excitability, capable of measuring degrees of startle response and evaluating prepulse inhibition. As mentioned, a number of valuable results were obtained using electrophysiological processes, including recordings of EMG, EEG, LTP (long-term potentiation of the hippocampus) and eye blink conditioning. Influencing of cerebral degeneration by neurotransplantation (embryonic cerebellar tissue or stem cells) or topical administrations of precisely defined substances were performed stereotactically. A number of experiments were then supplemented by microscopic examinations using a regular light microscope, as well as a fluorescent microscope and laser confocal fluorescent microscope.

\section{Overview of knowledge obtained}

Among the first results it is worth mentioning findings obtained back at the Department of Physiology 
UCL, that, in the case of $+/ \mathrm{Lc}$, the neuron sensitivity of the inferior olive to neurotoxin 3-acetylpyridine is already notable in the early post-natal period, prior to their secondary degeneration (after the extinction of the Purkinje cells) (Caddy and Vožeh 1997). Later, in the first experiments already conducted in the pilsener laboratory, using both the methods of passive avoidance and, in particular, the Morris water maze, it was possible to initially prove and gradually confirm that the cerebellum, in fact, significantly contributes to cognitive functions (Vožeh et al. 1997, Vožeh et al. 1998, Vožeh et al. 1999, Vožeh et al. 2001, Cendelín and Vožeh 2002, Cendelín et al. 2003).

Interesting findings also regarded the development of motor functions. Here, it became clearly evident that, despite their neurological impairment, mutant mice are capable of learning to a notable degree and significantly improving their motor skill through gradual training, compared with untrained individuals (Křǐžková and Vožeh 2004). A further finding achieved which we considered very significant, is the fact that both in the case of $+/ \mathrm{Lc}$ and $+/+$, forced motor activity had an additional positive effect on cognitive skills. Additionally, in trained animals of both groups, the negative effects of aging were delayed (Cendelín et al. 2007, Cendelín et al. 2008, Markvartová et al. 2010).

Among other interesting findings regarding Lurcher mice we must mention that, despite the exact same impairment, identical phenotype symptomatology as well as cerebellar histology (Purkartová and Vožeh 2013, Kolinko et al. 2016), strain differences appeared in a number of experiments. These were apparent not only in the $+/$ Lc strains $\mathrm{C} 3 \mathrm{H}$ and B6CBA, but also in $+/+$. This was particularly the case in spatial orientation and learning, but also partly in the development of motor skills. While in the Morris maze, individuals from the B6CBA strain were clearly the best; these differences were not as apparent in most motor-skill tests and, in some, the $\mathrm{C} 3 \mathrm{H}$ mice performed better (Vožeh et al. 2002, Cendelín et al. 2014).

The differences given by the strain were also further proven in the monitoring of excitability and pain perception. Here, the excitability in both $+/$ Lc strains was higher than in $+/+$, but both healthy and impaired animals of the $\mathrm{C} 3 \mathrm{H}$ strain showed higher excitability compared with B6CBA individuals. The situation was slightly different in pain response where, in the 'tail flick' test, animals of the B6CBA strain had a significantly lower threshold compared with $\mathrm{C} 3 \mathrm{H}$ mice. Even so, differences between healthy and impaired animals of both strains were not statistically significant. To the contrary, in the 'plantar' test, no significant strain differences were found. However, within the $\mathrm{C} 3 \mathrm{H}$ strain, +/Lc individuals had a significantly lower pain threshold than the $+/+$ subjects (Vožeh et al. 2001).

Subsequently, strain differences were also identified when monitoring the pharmacological effects on mediator systems where, for example, SCH 23390 a D1 dopamine receptor antagonist negatively affected the ability of spatial learning in both types of mice $(+/ \mathrm{Lc}$ and $+/+$ ) of the B6CBA strain, while the same effect only appeared in the $+/+$ group of the $\mathrm{C} 3 \mathrm{H}$ animals (Cendelín and Vožeh 2001, Vožeh et al. 2002). Regarding the dopaminergic system, differences between + Lc and $+/+$ in both strains in the area of distribution of the D1 and D2 receptors were further identified. Here, the $+/$ Lc strain of B6CBA showed a significantly higher density of both these receptors in the hippocampus. In the case of $\mathrm{C} 3 \mathrm{H}$ animals, only the number of $\mathrm{D} 1$ receptors was increased. In the case of the $+/ \mathrm{Lc}$ strain of B6CBA, D1 receptors had a lower density in the cerebellum, while D2 receptors were not impaired. In the striatum, the density of both receptors in the $+/$ Lc mice was comparable to results of both strains of $+/+$ (Mysliveček et al. 2007).

In electrophysiologically focused experiments, were subsequently monitored the hippocampal LTP by affecting the availability of the gaseous mediator - nitric oxide (NO). Here interesting results were also achieved, including strain differences. Additionally, the effect of administration of L-arginine (L-Arg), a substrate for NO synthesis, and nitro-L-arginine (nL-Arg), an inhibitor of NO synthase (NOS), and their subsequent effects were monitored in adult animals of both types and both strains (+/Lc, +/+; C3H, B6CBA). In the case of animals of the $+/+$ strain of $\mathrm{C} 3 \mathrm{H}$, the administration of the NOS inhibitor significantly decreased the amplitude of LTP potentials, while the higher availability of NO (upon administering L-Arg) caused their significant increase. In the case of the $+/$ Lc of the same strain, the identical effect was only notable upon the administration of NOS inhibitor, while the increase of NO availability (after L-Arg) remained without a response. The results in animals of the B6CBA strains were generally similar as in $\mathrm{C} 3 \mathrm{H}$ individuals, however with the difference that administration of L-Arg paradoxically caused a decrease of LTP potentials in +/+ animals (Barcal et al. 2001).

Among other experiments with various 
functional and morphological consequences of cerebellar degeneration in $+/ \mathrm{Lc}$ mice, the findings obtained through a collaboration with histologists stand out. In this case, that this neurodegenerative process was also found to affect the immune and endocrine functions, which confirmed the concept of interconnection of the psychoneuro-endocrine-immune system. Here, significant changes were observed in both immunocompetent (thymus, spleen, lymphatic nodes) and endocrine (both adrenal cortex and medulla) organs. Generally, these were changes in the sense of regression with signs of weakening function, here also with minor strain differences (Beranová et al. 2002, Vožeh et al. 2002, Vožeh et al. 2014). As was subsequently confirmed by more recent works, abnormal stress reactions were proven in $+/ \mathrm{Lc}$, undoubtedly related to the impairment of regulation on the HPA axis (hypothalamus - pituitary gland - adrenal glands) (Hilber et al. 2004, Tůma et al. 2017).

As mentioned above, our research on cerebellum degeneration began in a foreign laboratory and the international collaboration focusing on this subject then continued, as it does today. Results of the last two areas of the research, the overview of which is the main goal of this work, may serve as examples. The first are results achieved through collaboration with colleagues from the Pablo de Olavide University, Seville, Spain, regarding the contribution of the cerebellum to excitability and, particularly the participation of cerebellar nuclei in eye blink conditioning. This study also identified certain differences between $+/ \mathrm{Lc}$ and $+/+$, particularly regarding the reflex response to electric stimulation, as an unconditioned stimulus. However, the effect of the lesion of the cerebellar interpositus nucleus, the participation of which on the conditioning of this reflex is without a doubt, was comparable in both types of animals. Nonetheless, some electrophysiologically registered signs of compensation of the missing neurons in the cerebellar cortex were found in the case of $+/ \mathrm{Lc}$ (Porras-Garcia et al. 2005, Porras-Garcia et al. 2010).

The last significant activity, on which the research was focused over ten years, was the effort to affect various types of cerebellar degenerations through neurotransplantations. The activity in this field was launched at the Department of Neuroscience and Rita Levi Montalcini Centre for Brain Repair, University of Turin, Italy, in the laboratory of Professor Rossi. The processes of the embryonic cerebellar tissue transplantations were then transferred from Turin to the laboratory of the Department of Pathophysiology in Pilsen.

A transplant was introduced to the impaired as well as healthy individuals, either as a solid particle of an embryonic tissue or as a suspension of embryonic, stem and other cells. So, thus both mice of the B6CBA and $\mathrm{C} 3 \mathrm{H}$ strains were affected, as well as the PCD and SCA2 mice (Cendelín et al. 2009, Houdek et al. 2011, Houdek et al. 2012, Cendelín 2014). The period of survival of the transplant was monitored, along with its morphology, in different periods after the transplantation and functional effects (Cendelín et al. 2012, Purkartová et al. 2014, Babuška et al. 2015, Cendelín 2016).

\section{Conclusions}

Despite certain difficulty in transposing the experimental finding into human medicine, it must be stated that some experimental findings can be applied to humans. First, it should be stressed that in case of existing neurological impairment, its impacts could be positively affected. An example is the above mentioned (forced) physical activity that significantly improved not only motor skills but also cognitive functions. It is no less important that this effect was equally apparent in both impaired individuals and control groups. It also proved to significantly defer negative effects of aging in both the area of motor skills and cognition, both in impaired and control healthy mice.

Transposed to humans, these experimental findings confirm the enormous significance of rehabilitation in case of most neurological defects, whether congenital or acquired. The positive effect of physical activity on the improvement of motor skills, as well as cognitive functions and overall psychological condition, is particularly encouraging.

The remaining problem is the prevention of the development of congenital, in our case cerebellar, degenerations. Pharmacotherapy certainly represents some options, but without hope on a success, also are not above mentioned neurotransplantation.

Nevertheless, despite certain evident improvements, these cannot currently be recommended as a treatment method, because the effect was not always convincing and was often likely caused by the effect of stimulation of formation of endogenic or transplantsupplied substances, such as growth factors (Vožeh 2015, Cendelín et al. 2018).

An additional problem also remains in the fact that cerebral tissue affected by neurodegeneration 
(although not in all models used) is not very favorable for graft transplantation, unlike the environment that is more receptive in healthy tissues. However, neurotransplantation that produces more promising results in other neurodegenerations (e.g. Parkinson's disease) remains a significant therapeutic hope for human spinocerebellar ataxias as well.

\section{Conflict of Interest}

There is no conflict of interest.

\section{Acknowledgements}

This study was supported by the Charles University Research Fund (project number Q39) and by the National Sustainability Program I (NPU I) Nr. LO1503 provided by the Ministry of Education Youth and Sports of the Czech Republic. The author would like to thank to Mrs. Michaela Freeman for language editing the manuscript.

\section{References}

BABUŠKA V, HOUDEK Z, TƯMA J, PURKARTOVÁ Z, TU゚MOVÁ J, KRÁLÍČKOVÁ M, VOŽEH F, CENDELÍN $\mathrm{J}$ : Transplantation of embryonic cerebellar grafts improves gait parameters in ataxic Lurcher mice. Cerebellum 14: 632-641, 2015.

BARCAL J, VOŽEH F, ŽALUD V: Hippocampal electrical activity in two strains of Lurcher mutant mice. Homeostasis 41: 200-202, 2001.

BERANOVÁ M, MANĎÁKOVÁ P, ŠÍMA P, SLÍPKA J, VOŽEH F, KOČOVÁ J, ČERVINKOVÁ M, SÝKORA J: Morphology of adrenal gland and lymph organ is impaired in neurodeficient Lurcher mutant mice. Acta Vet 71: 23-28, 2002.

BUCKNER RL: The cerebellum and cognitive function: 25 years of insight from anatomy and neuroimaging. Neuron 80: 807-815, 2013.

CADDY KW, BISCOE TJ: Structural and quantitative studies on the normal C3H and Lurcher mutant mouse. Philos Trans R Soc Lond B Biol Sci 287: 167-201, 1979.

CADDY KW, VOŽEH F: The effect of 3-acetylpyridine on inferior olivary neuron degeneration in Lurcher mutant and wild-type mice. Eur J Pharmacol 330: 139-142, 1997.

CENDELÍN J, VOŽEH F: Comparison of the effect of the D1 dopamine receptor influencing on spatial learning in two different strains of Lurcher mutant mice. Homeostasis 41: 73-78, 2001.

CENDELÍN J, VOŽEH F: Comparison of some neural functions in two different strains of Lurcher mutant mice. Acta Physiol Hungarica 89: 189, 2002.

CENDELÍN J, KORELUSOVÁ I, VOŽEH F: Preliminary study of the effect of repeated motor training on spatial learning ability in adult Lurcher mutant mice. Prague Med Report 108: 49-56, 2007.

CENDELÍN J, KORELUSOVÁ I, VOŽEH F: The effect of repeated rotarod training on motor skills and spatial learning ability in Lurcher mutant mice. Behav Brain Res 189: 65-74, 2008.

CENDELÍN J, KORELUSOVÁ I, VOŽEH F: A preliminary study of solid embryonic cerebellar graft survival in adult B6CBA Lurcher mutant and wild type mice. Anat Rec (Hoboken) 292: 1986-1992, 2009.

CENDELÍN J, BABUŠKA V, KORELUSOVÁ I, HOUDEK Z, VOŽEH F: Long-term survival of solid embryonic cerebellar grafts in Lurcher mice. Neurosci Lett 515: 23-27, 2012.

CENDELÍN J, TƯMA J, KORELUSOVÁ I, VOŽEH F: The effect of genetic background on behavioral manifestation of Grid2(Lc) mutation. Behav Brain Res 271: 218-227, 2014.

CENDELÍN J: From mice to men lessons from mutant ataxic mice. Cerebellum Ataxias 1: 4, 2014.

CENDELÍN J: Neurotransplantation and stem cell therapy for cerebellar degenerations. Cerebellum 15: 48-50, 2016.

CENDELÍN J, MITOMA H, MANTO M: Neurotransplantation therapy and cerebellar reserve. CNS Neurol Dis Drug Targets 17: 172-183, 2018.

DENNIS J, SCHUTTER LG: Human cerebellum in motivation and emotion. In: Handbook of the Cerebellum and Cerebellar Disorders. MANTO M, GRUOL DL, SCHMAHMANN JD, KOIBUCHI N, ROSSI F. (eds), New York: Springer Science + Business Media, 2013, pp 1499-1521.

GLICKSTEIN M: The cerebellum and motor learning. Cur Opin Neurobiol 2: 802-806, 1992. 
HERCULANO-HOUZEL S: Coordinated scaling of cortical and cerebellar numbers of neurons. Front Neuroanat 4: Article 12, 1-8, 2010.

HILBER P, LORIVEL T, DELARUE C, CASTON J: Stress and anxious-related behaviors in Lurcher mutant mice. Brain Res 1003: 108-112, 2004.

HOUDEK Z, CENDELÍN J, KULDA V, BABUŠKA V, VOŽEH F, HATINA J, KRÁLÍČKOVÁ M, ZECH NH, VESELÁ I, PACHERNÍK J, UHER P: Comparison of P19-derived neuroprogenitor and naive cell survival after intracerebellar application into B6CBA mice. Folia Biol (Praha) 57: 162-169, 2011.

HOUDEK Z, CENDELÍN J, KULDA V, BABUŠKA V, ČEDÍKOVÁ M, KRÁLÍČKOVÁ M, PACHERNÍK J, STEFANO GB, VOŽEH F: Intracerebellar application of P19-derived neuroprogenitor and naive stem cells to Lurcher mutant and wild type B6CBA mice. Med Sci Monit 18: 74-180, 2012.

KOLÍNKO Y, CENDELÍN J, KRÁLÍČKOVÁ M, TONAR Z: Smaller absolute quantities but greater relative densities of microvessels are associated with cerebelllar degeneration in Lurcher mice. Front Neuroanat 10: 35, 2016.

KŘİŽKOVÁ A, VOŽEH F: Development of early motor learning and topical motor skills in a model of cerebellar degeneration. Behav Brain Res 150: 65-72, 2004.

MALINOVÁ-ŠEVČÍKOVÁ M, HREBÍČKOVÁ I, MACÚCHOVÁ E, NOVÁ E, POMETLOVÁ M, ŠLAMBEROVÁ R: Differences in maternal behavior and development of their pups depend on the time of methamphetamine exposure during gestation period. Physiol Res 63 (Suppl 4): S559-S572, 2014.

MARKVARTOVÁ V, CENDELÍN J, VOŽEH F: Changes of motor abilities during ontogenetic development in Lurcher mutant mice. Neurosci 168: 646-651, 2010.

MIDDLETON FA, STRIK PL: Cerebellar projections to the prefrontal cortex of the primate. $J$ Neurosci 21: 700-712, 2001.

MYSLIVEČEK J, CENDELÍN J, KORELUSOVÁ I, KUNOVÁ M, MARKVARTOVÁ V, VOŽEH F: Changes of dopamine receptors in mice with olivocerebellar degeneration. Prague Med Report 108: 57-66, 2007.

PHILLIPS RJS: „Lurcher“, a new gene in linkage group XI of the house mouse. $J$ Genet 57: 35-42, 1960.

PORRAS-GARCIA E, CENDELÍN J, DOMÍNGUEZ-DEL-TORO E, VOŽEH F, DELGADO-GARCIA JM: Purkinje cell loss affects differentially the execution, acquisition and prepulse inhibition of skeletal and facial motor responses in Lurcher mice. Eur J Neurosci 21: 979-988, 2005.

PORRAS-GARCIA E, SÁNCHEZ-CAMPUSANO R, MARTINEZ-VARGAS D, DOMÍNGUEZ-DEL-TORO E, CENDELÍN J, VOŽEH F, DELGADO-GARCIA JM: Behavioral characteristics, associative learning capabilities, and dynamic association mapping in an animal model of cerebellar degeneration. $J$ Neurophysiol 104: 346-365, 2010.

PURKARTOVÁ Z, VOŽEH F: Cerebellar degeneration in Lurcher mice under confocal laser scanning microscope. Microsc Res Tech 76: 545-551, 2013.

PURKARTOVÁ Z, TƯMA J, PEŠTA M, KULDA V, HÁJKOVÁ L, ŠEBESTA O, VOŽEH F, CENDELÍN J: Morphological analysis of embryonic cerebellar grafts in SCA2 mice. Neurosci Lett 558: 154-158, 2014.

SCHMAHMANN JD: From movement to thought: anatomic substrates of the cerebellar contribution to cognitive processing. Hum Brain Mapp 4: 174-198, 1996.

SCHMAHMANN JD, PANDYA DN: The cerebellar system. Int Rev Neurobiol 41: 31-60, 1997.

SCHMAHMANN JD, SHERMAN JC: Cerebellar cognitive affective syndrome. Int Rev Neurobiol 41: 433-440, 1997.

TŮMA J, KOLÍNKO Y, JELÍNKOVÁ D, CENDELÍN J: Impaired spatial performance in cerebellar-deficient Lurcher mice is not associated with their abnormal stress response. Neurobiol Learn Mem 140: 62-70, 2017.

TÜDÖS Z, HOK P, HLUŠTÍK P, GRAMBAL A: Functional MRI study of gender effects in brain activations during verbal working memory task. Physiol Res 67: 825-829, 2018.

VOŽEH F, CADDY KWT, MYSLIVEČEK J, MOTÁŇOVÁ A: Some characteristics of early learning in cerebellar degeneration model. Stud Psychol (Bratisl) 39: 279-281, 1997.

VOŽEH F, CADDY KWT, MYSLIVEČEK J: Některé morfologické a funkční charakteristiky animálního modelu mozečkové degenerace. (In Czech) Cesk Fyziol 47: 74-78, 1998.

VOŽEH F, CENDELÍN J, MOTÁŇOVÁ A: The development of different types of learning in cerebellar degeneration model. Homeostasis 39: 248-250, 1999. 
VOŽEH F, CENDELÍN J, ŠTENGLOVÁ V, BARCAL J: Development of spatial learning in a model of olivocerebellar degeneration. Homeostasis 41: 64-66, 2001.

VOŽEH F, CENDELÍN J, YAMAMOTOVÁ A, ROKYTA R: CNS excitability and pain perception in two strains of mice afflicted with the same type of cerebellar degeneration (Lurcher mutants). Homeostasis 41: 196-199, 2001.

VOŽEH F, BARCAL J, CENDELÍN J, KŘÍŽKOVÁ A: Contribution to the development of cognitive functions in model of olivocerebellar degeneration. Cesk Fyziol 51: 136-137, 2002.

VOŽEH F, SLÍPKA J, KRÁLÍČKOVÁ M: Lurcher mice - a model not only cerebellar degeneration but also neuroendocrino-immune consequences. Comparative morphology (in Czech). Abstracts, Symposium held in honor of prof. MD. RNDr. Jaroslav Slipka, DSc., held in Pilsen on January 14, 2014 by Department of Histology and Embryology and Department of Anatomy, Faculty of Medicine in Pilsen, Charles University and by Czech Anatomical Society, 39-42, 2014.

VOŽEH F: Jan Evangelista Purkyně and the cerebellum then and now. Physiol Res 64 (Suppl 5): S567-S584, 2015. 